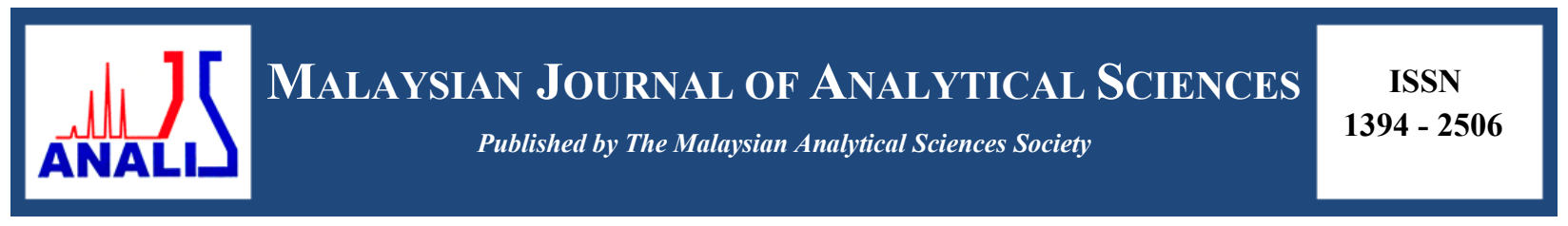

\title{
ANTIULCER ACTIVITY OF Musa paradisiaca (BANANA) TEPAL AND SKIN EXTRACTS IN ULCER INDUCED ALBINO MICE
}

\section{(Aktiviti Antiulser dari Ekstrak Jantung dan Kulit Musa paradisiaca (Pisang) pada Tikus Albino Teraruh Ulser)}

\author{
U.S Mahadeva Rao ${ }^{1}$, Bashir Ado Ahmad ${ }^{1}$, Khamsah Suryati Mohd $^{2,3}$, Thant Zin ${ }^{1}$ \\ ${ }^{I}$ Faculty of Medicine, \\ Universiti Sultan Zainal Abidin, Medical Campus, 21400 Kuala Terengganu, Terengganu, Malaysia \\ ${ }^{2}$ Faculty of Bioresources and Food Industry \\ ${ }^{3}$ Agriculture Production and Food Innovation Research Institute \\ Universiti Sultan Zainal Abidin, Tembila Campus, 22200 Besut, Terengganu, Malaysia
}

*Corresponding author: dambash011@yahoo.com

Received: 14 April 2015; Accepted: 3 August 2016

\begin{abstract}
The current use of ulcer drugs is limited due to its side effects and potentiality of relapse. This study aimed to ascertain the antiulcer potentials of the tepal and skin extracts of banana Musa paradisiaca. The parts were processed and extracted using methanol by maceration. Phytochemicals content of both parts were screened. Twenty-five albino mice were used in in vivo analysis. The mice were treated with $100 \mathrm{mg} / \mathrm{kg}$ of tepal and skin extract as well as cimetidine for seven days followed by administration of indomethacin. The animals were sacrificed, and the removed stomachs were prepared for the evaluation of ulcer index and gastric wall mucus. $\mathrm{pH}$ and volume were measured from the gastric juice. The results revealed that banana's tepal and skin extracts contain phytochemicals like phenols, flavonoids and etc. The tepal and skin extracts prevented the IND+PYL induced ulcer by $68.80 \pm 20.53 \%$ and $43.22 \pm 14.82 \%$ respectively. Significant rise $(\mathrm{p}<0.05)$ in gastric juice $\mathrm{pH}(3.79$ $\pm 0.24)$ was noticed in the banana's tepal treated group. However, the decrease in gastric juice volume and increased gastric wall mucus by both tepal and skin were not statistically significant $(\mathrm{p}>0.05)$. Findings from this study shows that banana's tepal and skin were able to prevent IND+PYL induced ulcer by strengthening the gastric mucosa and decreasing the gastric juice acidity.
\end{abstract}

Keywords: banana's tepal, banana's skin, indomethacin, Musa paradisiaca, preventive index

\section{Abstrak}

Penggunaan ubat ulser pada masa kini adalah terhad disebabkan kesan sampingan dan potensi kambuh. Kajian ini bertujuan menentukan potensi antiulser dari ekstrak jantung dan kulit pisang Musa paradisiaca. Bahagian - bahagian ini telah diproses dan diekstrak menggunakan metanol melalui kaedah rendaman. Kandungan fitokimia kedua - dua bahagian telah disaring. Dua puluh lima tikus albino telah digunakan dalam analisis in vivo. Tikus - tikus ini telah diberi rawatan dengan $100 \mathrm{mg} / \mathrm{kg}$ ekstrak jantung dan kulit pisang serta simetidin selama tujuh hari di ikuti dengan rawatan dengan indomethacin. Haiwan dikorbankan selepas 8 hari rawatan, dan perut dikeluarkan bagi penilaian indeks ulser dan mukus dinding perut. $\mathrm{pH}$ dan jumlah jus gastrik juga diukur. Hasil kajian mendapati bahawa ekstrak jantung dan kulit pisang mengandungi beberapa fitokimia seperti fenol, flavonoid, dan lain - lain. Ekstrak jantung dan kulit ini menghalang ulser yang diaruh dengan IND+PYL masing - masing sebanyak $68.80 \pm 20.53 \%$ dan $43.22 \pm 14.82 \%$. Peningkatan yang signifikan $(\mathrm{p}<0.05)$ pada $\mathrm{pH}$ jus gastrik $(3.79 \pm 0.24)$ telah diperhatikan dalam kumpulan yang dirawat dirawat dengan jantung pisang. Walau bagaimanapun, penurunan dalam jumlah jus gastrik dan meningkatkan mukus dinding perut oleh kedua - dua ekstrak adalah tidak signifikan secara statistik ( $p>0.05)$. Dapatan dari kajian ini menunjukkan bahawa jantung dan kulit pisang dapat mencegah ulser yang diaruh dengan IND + PYL melalui penambahan mukosa perut dan pengurangan keasidan jus gastrik. 


\section{Rao et al: ANTIULCER ACTIVITY OF Musa paradisiaca (BANANA) TEPAL AND SKIN EXTRACTS IN}

ULCER INDUCED ALBINO MICE

Kata kunci: jantung pisang, kulit pisang, indomethacin, Musa paradisiaca, indeks pencegahan

\section{Introduction}

Ulcers are simply lesions penetrating the thickness of the gastrointestinal tract (G.I.T) mucosa [1]. The etiology of gastro-duodenal (peptic) ulcer has therefore developed when aggressive factors such as, increased HCL and pepsin secretion, parietal cell mass, and gastrin production, dominate the defensive factors (PGs, increased mucous cells etc) $[2,3]$.

Indomethacin, a NSAID (methylated indole derivative), was introduced in 1963 for the management of inflammatory diseases such as rheumatoid arthritis, degenerative joint diseases, gout, and acute musculoskeletal disorders $[4,5]$. However it was later found to be injurious to tissues. These injurious effects have been ascribed to the production of reactive oxygen species (ROS) [6,7], which lead to oxidative stress and initiation of lipid peroxidation [7], infiltration of inflammatory cells [8,9]. Pylorus ligation also induced ulcers by increasing the accumulation of gastric acid and pepsin that lead to auto digestion of the gastric mucosa and the breakdown of gastric mucous [10]. Hence, indomethacin and pylorus ligation were used to induce ulcer in this research.

The major idea behind treating ulcers is to lower the amount of acid that the stomach makes, to neutralize the acid and to protect the injured area so it can have time to heal [1]. However, most of the commonly used antiulcer drugs, namely antacids, H2- blockers and proton pump inhibitors, etc. that mainly act by reducing the aggressive factors are reported to have adverse effects, development of tolerance and increased the incidence of relapses during ulcer therapy [11]. The expensive costs and toxic effect of these agents, necessitate efforts to find a suitable protective agent, for the treatment of peptic ulcer disease from natural products of plants, which afford better protection and decrease the incidence of relapse that is affordable by all classes of people. Interestingly, herbal drugs mostly augment the defensive factors such as mucin secretion, cellular mucus, bicarbonate secretion and mucosal blood flow [12].

Banana is one of the oldest and well-known fruit worldwide. The leaf and stem of banana are use to treat diarrhoea; the stem is good for asthenia and wounds, and the leaf for the treatment of inflammation, headache and rheumatism [13]. Besides to its nutritional value, a number of biological activities studies have been carried out on banana and these studies prove it to possess bioactivities including anti-hyperglycaemic, antiulcerogenic, antioxidant, antihypertensive, cardiac depressant, diuretic, anti-tumoral, bronchodilatory, expectorant, oral contraceptive, abortifacient, antibacterial, antifungal and etc. [14]. Therefore, this study was carried out to evaluate the antiulcer effect of Musa paradisiaca tepal (a part mostly considered as a waste) and skin, against indomethacin plus pylorus ligation induced gastric injury in mice.

The economy of developing countries has a lot to do with the health status of its citizen. The rising incidence of ulcer has involved both adults and children. The solution to ulcer will help in controlling health status, societal and physical well-being as well as economic uplift of individuals, families, companies and nation at large.

\section{Collection and preparation}

\section{Materials and Methods}

Banana fruit and tepal, were purchased from Kuala Terengganu, Malaysia; samples were identified and authenticated by Dr. Khamsah Suryati Mohd from the Faculty of Bioresources and Food industry, Universiti Sultan Zainal Abidin. The skin (peel) was removed from the fruit, sliced, and weighed using electrical balance $(1.45 \mathrm{~kg})$. It was then dried in a drier at $45^{\circ} \mathrm{C}$; the dry weight is $0.41 \mathrm{~kg}$. After drying, it was blended to powder, using an electrical blender, and the weight is $0.21 \mathrm{~kg}$. The tepal was also prepared in a similar way and weighed $(3 \mathrm{~kg})$ and dried at $40{ }^{\circ} \mathrm{C}$ and then blended to powder $(0.42 \mathrm{~kg})$.

\section{Extraction procedure}

The prepared skin and tepal were extracted twice with methanol $(10: 2 \mathrm{~mL} / \mathrm{kg})$ by cold extraction technique. The samples were put in the solvents for about 3 days at room temperature with regular shaking. All the extracts were 
vacuum filtered using Whatman number one filter paper and concentrated at $40{ }^{\circ} \mathrm{C}$ using a rotary evaporator. The crude extracts were kept in a fresh vials and refrigerated at $4^{\circ} \mathrm{C}$ for further study.

\section{Phytochemical screening of the extracts}

The phytochemicals screening of the various solvents extract were carried out using standard procedures [15].

\section{Test for glycosides}

Small amount of the extracts was put in $1 \mathrm{~mL}$ of water in a test tube followed by the addition of $1 \mathrm{~mL}$ of $\mathrm{NaOH}$. A yellow precipitate indicates the presence of glycosides.

\section{Test for phenols}

The extract $(5 \mathrm{mg}$ ) was dissolved in distilled water and $3 \mathrm{~mL}$ of $10 \%$ lead acetate solution was added. A bulky white precipitates indicated the presence of phenols.

\section{Test for flavonoids}

A few drops of concentrated hydrochloric acid were added to a small amount of the extract. Immediate development of red colour indicates the presence of flavonoids.

\section{Test for saponins}

An amount $1 \mathrm{~mL}$ of each extract was diluted with distilled water to $20 \mathrm{~mL}$ and shaken in a graduated cylinder for 15 $\min$. The formation of foam of about $1 \mathrm{~cm}$ indicates the presence of saponins.

\section{Evaluation of antiulcer activity}

Swiss albino mice of both sexes (30-35g), obtained from UniversitI Sains Malaysia Pinang, were utilized in this experiment. The animals were kept in cages with proper bedding. The bedding was regularly changed to prevent coprophagy. The animals were put up in an ambient temperature of $22 \pm 1^{\circ} \mathrm{C}$ in a 12 hours light-dark bicycle. They were fed a standard balanced diet and given free access to water ad libitum. All animals were fasted for 24 hours [16] to ensure an empty stomach before use in the experiment. The experiments were designed and conducted to meet the ethical norms approved by University Sultan Zainal Abidin, Malaysia, animal ethical committee (UniSZA/AEC/14/006).

\section{Study design}

The experimental models were acclimatized for one week. They were then randomly grouped into five groups comprising of five mice each. Group I served as normal control, which received $0.3 \mathrm{ml} / 30 \mathrm{~g}$ distilled water for 7 days. Group II or IND+PYL group was induced with indomethacin at a single dose of $48 \mathrm{mg} / \mathrm{kg}$ [17] body weight (b.wt) on the $7^{\text {th }}$ day of the experiment. Group III or TPM group was also orally administered methanol extract of the tepal at a dose of $100 \mathrm{mg} / \mathrm{kg} \mathrm{b}$. wt and then indomethacin at a single dose of $48 \mathrm{mg} / \mathrm{kg}$ on the $7^{\text {th }}$ day, one hour after the last treatment. Group IV or SKM and V or CIM were treated in the same manner as group III. All animals were allowed to fast overnight. On the $8^{\text {th }}$ day, pylorus was ligated using silk sutures as per the method [18] under light ether anaesthesia, taking care not to temper with the blood vessels. Then after the abdominal wall was closed by suturing and the animals were allowed to recover from the anaesthesia for 4 hours, ketamine was used to euthanize it. Each stomach was removed and opened along the greater curvature, washed with $0.9 \%$ saline and examined for macroscopic mucosal lesions, with the aid of magnifying glass (x10), and then put inside a container containing 10\% formasaline and kept for histopathological studies. The gastric content was carefully collected for analysis.

\section{Calculation of macroscopic ulcer index (U.I)}

The severity of the ulceration was graded according to the scale that is a modification of the score [19].

(0 - Normal gray colored stomach), (0.5 - Pink to red coloration of the stomach), (1 - Spot ulcer), (1.5 Haemorrhagic streak), (2 - Number of ulcers less than 5), (3 - Number of ulcers more than or equal to 5), (4 - Ulcer with bleeding) and (5 - Perforation of the gastric/duodenal wall). 
Ulcer Index was calculated by summing the entire number of ulcers plus the severity of the ulcer. The preventive index (P.I) of the extract administered was obtained by using the equation 1[20].

$$
P . I=\frac{\text { U.I of indomethacin group }-U . I \text { of test group }}{\text { U.I of indomethacin group }} \times 100
$$

\section{Determination of gastric juice volume and $\mathrm{pH}$}

After the gastric contents were collected and centrifuged at $1000 \mathrm{rpm}$ for $10 \mathrm{~min}$. The volume of the supernatant was determined in $\mathrm{mL}$. The $\mathrm{pH}$ of the supernatant was measured using a $\mathrm{pH}$ meter [21,22].

\section{Assessment of gastric wall mucus}

Alcian blue binding to gastric wall mucus was determined by a modified method of Corne [23]. The stomach of each mice was weighed and immediately transferred to $10 \mathrm{~mL}$ of $1 \%(\mathrm{w} / \mathrm{v})$ alcian blue solution (in $0.16 \mathrm{M}$ sucrose solution, buffered with $0.05 \mathrm{~mL}$ sodium acetate, $\mathrm{pH}$ 5) for 2 hours at room temperature. After 2 hours, the stomachs were removed, rinsed with $0.25 \mathrm{M}$ sucrose solution to remove excess dye after 15 and 45 minutes, and the dye complexed with gastric wall mucus was extracted with $10 \mathrm{~mL}$ of $0.5 \mathrm{M} \mathrm{MgCl}_{2}$ solution by intermittent shaking for 1 minute at 30 minutes' intervals for 2 hours. The stomachs were removed and $5 \mathrm{~mL}$ of each aliquot of $\mathrm{MgCl}_{2}$ solution containing the alcian blue eluted from each stomach was shaken with $4 \mathrm{~mL}$ of diethyl ether. The aqueous phase was separated out, centrifuged at $4000 \mathrm{x}$ g for $16 \mathrm{~min}$ and the absorbance of the supernatant was measured at $580 \mathrm{~nm}$. The amount of alcian blue bound per stomach in micrograms was determined using a standard calibration curve. Alcian blue was the standard compound used.

\section{Histopathological studies: Tissue preparation}

After the lesions seen in the stomachs had been noted, each stomach was then placed in $10 \%$ formasaline. After 24 hours of fixation followed by embedding, using closed type automated embedding machine, in a paraffin block, it was then trimmed and cut into sections of 5 microns, the ribbon obtained was put in a water bath $\left(56^{\circ} \mathrm{C}\right)$, fished out onto a glass slide and stained with haematoxylin-eosin stain for histological assessment of the gastric mucosa [24].

\section{Phytochemicals present in Musa paradisiaca tepal and skin}

\section{Results and Discussion}

The tepal and skin methanol extracts of Musa paradisiaca, prepared in this work showed the presence of the tested phytochemicals like flavonoids, phenols and glycosides.

Investigations into natural products often, is guided by ethno-pharmacological knowledge, and has brought tremendous contributions to drug production by providing novel chemical structures and mechanisms of action $[25,26]$. Tepal methanol extract showed the presence of glycosides and phenols in abundance. Flavonoids and saponins were also detected in this extract. Skin methanol extract also contains glycosides and phenols yet saponins are absent (Table 1).

Table 1. Phytochemicals from the tepal and skin methanol extracts of Musa paradisiaca

\begin{tabular}{lcccc}
\hline Extract & Glycosides & Phenols & Flavonoids & Saponins \\
\hline Tepal & ++ & ++ & + & + \\
Skin & + & + & ++ & - \\
\hline
\end{tabular}

Note: $++=$ present in abundance. $+=$ present. $-=$ Absent

Plant secondary metabolites, are important sources of many food ingredients and plant chemicals (phytochemicals) [27]. Recent researches showed that many phytochemicals can protect humans against various diseases [28]. Many phytochemicals are present in herbs, and each has its distinct work. The health benefits attributed to these 
phytochemicals include; antioxidant, antimicrobial, anti-inflammatory, cancer preventive, antidiabetic and antihypertensive effects $[29,30]$.

Preliminary phytochemical screening of dried leaves and fruit peels of Musa paradisiaca unveil the presence of some glycosides, anthocyanins, tannins, flavonoids as well as carbohydrates [31-33]. These phytochemicals have been reported to play multiple biological and pharmacological roles (antibacterial, antihypertensive, antidiabetic and anti-inflammatory activities [34].

Several phytochemicals in different parts of banana from different solvent extracts have been reported by several researchers. Many flavonoids and related compounds (Leucocyanidin, quercetin, and its 3-O-galactoside, 3-Oglucoside and 3-O-rhamnosyl glucoside) were isolated from the unripe pulp of plantain [35,36]. Serotonin, norepinephrine, tryptophan, indole compounds, tannin, starch, iron, crystallizable and non-crystallizable sugars, vitamin C, B-complex vitamins, fats, mineral salts were detected in the fruit pulp of M. paradisiaca var. sapientum [37]. The preliminary phytochemical screening carried out indicated $M$. paradisiaca var. sapientum peels contain some secondary metabolites such as glycosides, alkaloids, saponins, volatile oil, flavonoids and tannins [38]. The phytochemical screening of ethanolic and methanolic extracts of Musa paradisiaca confirmed the presence of some secondary metabolites. Ethanolic extract was found to have alkaloids, flavonoids, steroids, tannins, glycosides etc., whereas the methanolic extract revealed the presence of alkaloids, saponins, xanthoproteins and glycosides [39].

The roles of these phytochemicals as both therapeutics and nutrients makes these parts (tepal and skin) of the plant have medicinal and nutritional values. This work confirmed the presence of most of these phytochemicals in the parts above.

\section{Effect of Musa paradisiaca tepal and skin on ulcer index}

Ligation of pylorus causes erosion due to stimulation of acid and pepsin in the abdomen [18], leading to autodigestion of the gastric mucosa and the breakdown of the gastric mucosal barrier [40]. Prostaglandins (PGs) shows a protective effect on the stomach mucosa and causes an increase in bicarbonate secretion, maintain mucosal blood flow and repair. Hence, the increase in mucosal lesions is caused by suppressing PGs synthesis by NSAIDs. For this reason, indomethacin plus pylorus ligation model was used in our study to induce severe ulceration in mice. The number of lesions seen on the gastric mucosa is an indication of the severity of ulcer disease [41]. Nonparametric Kruskal-Wallis followed by Mann-Whitney tests were used for the statistical analysis.

According to this result (Table 2), administration of indomethacin coupled to ligation of the pylorus in IND+PYL group showed significant increase in ulcer index $(16.20 \pm 5.70)$ when compared to the normal control group $(\mathrm{p}=$ $0.005)$. Pre-treatment with cimetidine significantly $(\mathrm{p}=0.009)$ decreases the ulcer index. Tepal pre-treatment also significantly decreases $(p=0.027)$ the ulcer index when compared to the induced group. However, the decrease in ulcer index in skin pre-treated group is not significant $(\mathrm{p}=0.074)$. The cimetidine pre-treated group decreased the ulcer index to $3.6 \pm 1.20$ giving $72.14 \%$ protection. Meanwhile, the tepal and skin extracts reduced the ulcer index to $3.60 \pm 1.20$ and $6.90 \pm 2.10$ giving $68.80 \%$ and $43.22 \%$ protection respectively. This protection (preventive index) observed in both the tepal and skin is not statistically significant from the protection observed in cimetidine $(\mathrm{p}=0.249)$.

The gastric mucosal integrity depends on the balance between HCL, pepsin (aggressive factors) and the protective factors as mucus and bicarbonate secretion, prostaglandins, mucosal blood flow, nitric oxide [42]. Hence, the main guidelines for the treatment are aimed not only at blocking the acid secretion, but also on the increased production of factors responsible for protecting the gastric mucosa, thus preventing epithelial damage [43]. The present study proves the preventive effect of Musa paradisiaca tepal and skin methanol extracts, as they significantly decreased the induced ulcer. 


\section{Rao et al: ANTIULCER ACTIVITY OF Musa paradisiaca (BANANA) TEPAL AND SKIN EXTRACTS IN}

ULCER INDUCED ALBINO MICE

Table 2. Effect of tepal and skin pre-treatments on ulcer index and preventive index in IND+PYL induced ulcer

\begin{tabular}{lcc}
\hline Sample $(\mathbf{n}=\mathbf{5})$ & $\begin{array}{c}\text { Ulcer Index } \\
\text { (Mean } \pm \mathbf{S E} \text { ) }\end{array}$ & $\begin{array}{c}\text { Preventive index } \\
\text { (Mean } \pm \text { SE) }\end{array}$ \\
\hline Control & $0.00 \pm 0.00^{\mathrm{c}}$ & Nil \\
IND+PYL & $16.20 \pm 5.70^{\mathrm{a}, \mathrm{d}}$ & Nil \\
Tepal pre-treated & $3.80 \pm 1.60^{\mathrm{b}}$ & $68.80 \pm 20.53^{\mathrm{e}}$ \\
Skin pre-treated & $6.90 \pm 2.10^{\mathrm{a}}$ & $43.22 \pm 14.82^{\mathrm{e}}$ \\
Cimetidine pre-treated & $3.60 \pm 1.20^{\mathrm{b}}$ & $72.14 \pm 13.49^{\mathrm{e}}$ \\
\hline
\end{tabular}

${ }^{\mathrm{a}, \mathrm{b}}$ Man-Whitney $\mathrm{U}$ test showed that, tepal methanol and cimetidine showed significant decrease in ulcer index. However, the decrease in skin extract is not statistically significant, when compared to the induced group (IND+PYL) ${ }^{a} \cdot{ }^{\mathrm{c}, \mathrm{d}}$ Man-Whitney $U$ test showed a significant formation of ulcer in IND+PYL group when compared to the normal control group. ${ }^{e}$ Kruskal-Wallis test showed no significant difference in ulcer prevention (Preventive ulcer index) exerted by the tepal, skin as well as the standard cimetidine drug.

\section{Effect of Musa paradisiaca tepal and skin on gastric juice volume and pH}

The current study showed that, the methanolic skin and tepal extracts of Musa paradisiaca, as well as cimetidine, lower the volume of the gastric juice compared to the induced group (IND+PYL). The volume of the gastric juice was found to be $0.86 \pm 0.13 \mathrm{~mL}$ in the induced (IND+PYL) group, but tepal brought it down to $0.40 \pm 0.04 \mathrm{~mL}$. Cimetidine and skin also reduced the volume to $0.46 \pm 0.08 \mathrm{~mL}$ and $0.64 \pm 0.13 \mathrm{~mL}$ respectively (Figure 1), although not statistically significant.

Significant increase in $\mathrm{pH}$ was observed in the tepal and cimetidine pre-treated groups as presented in Fig. 1. The $\mathrm{pH}$ value in the induced group (IND+PYL) was found to be $2.48 \pm 0.2$. This is significantly $(\mathrm{p}=0.012)$ increased to $3.79 \pm 0.24$ by the tepal extract in a similar way to the standard drug, cimetidine, $3.98 \pm 0.11(\mathrm{p}=0.009)$ when compared to the induced group. The increase in $\mathrm{pH}$ by the skin extract is not statistically significant $(\mathrm{p}=0.203)$ when compared to the induced group. This may be due to its less chemical components than the tepal or may be higher dosage is needed. However, it also increases the gastric juice $\mathrm{pH}$ to $2.99 \pm 0.32 \quad$ (Figure 1).

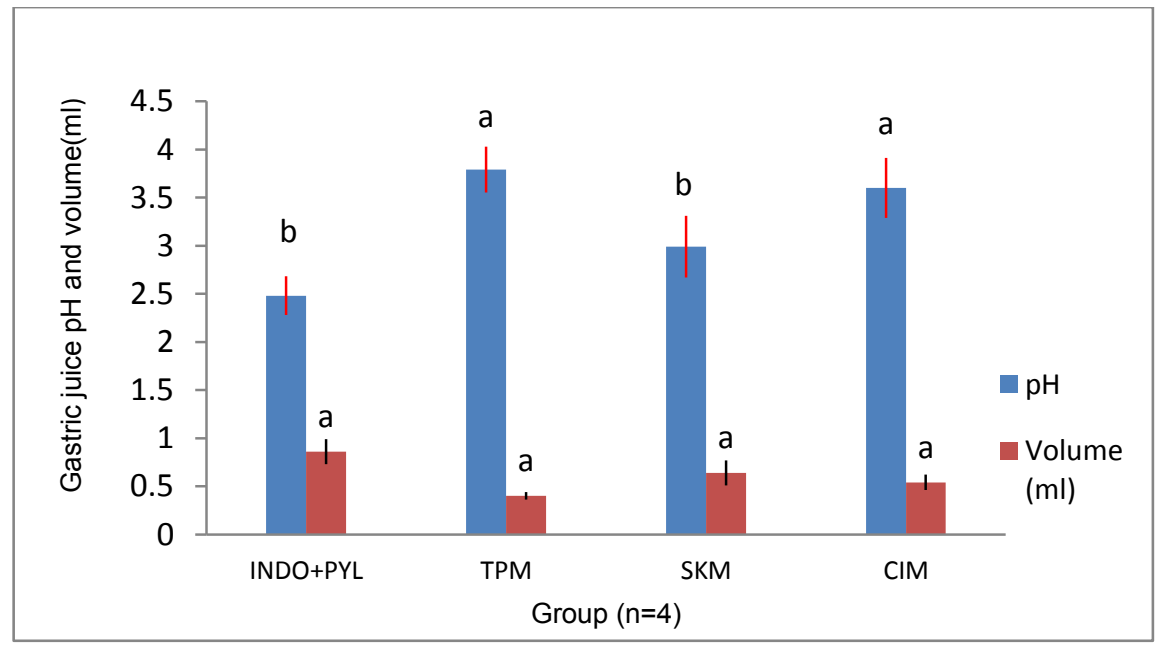

Figure 1. Gastric juice $\mathrm{pH}$ and volume 
Tepal methanol (TPM), cimetidine (CIM) and skin methanol (SKM) pre-treated groups showed no significant gastric juice volume reduction when compared to the induced group (INDO+PYL).

CIM and TPM showed a significant rise in $\mathrm{pH}$ when compared to the induced group (INDO+PYL). SKM showed no statistical significance when compared to the induced group.

\section{Effect of Musa paradisiaca tepal and skin on gastric wall mucus}

Figure 2 showed the impact of the tepal and skin extracts on the measured gastric wall mucus. Both the tepal and skin showed increased gastric mucus but not statistically significant $(p=0.339)$ when compared to the induced group (IND+PYL). The group pre-treated with the standard cimetidine drug also decreases the gastric mucus in a similar way to the tepal and skin.

The research shows the effects of tepal and skin against indomethacin plus pylorus ligation induced gastric ulcers. The gastric ulcers in the pylorus ligated animal are mainly due to increased gastric HCL secretion leading to the destruction of mucosal barrier and autodigestion of the gastric mucosal layer. In ulcer induced models there is, normally, a significant increase in the level of acid and pepsin [44]. Indomethacin also increases pepsinogen secretion [45].

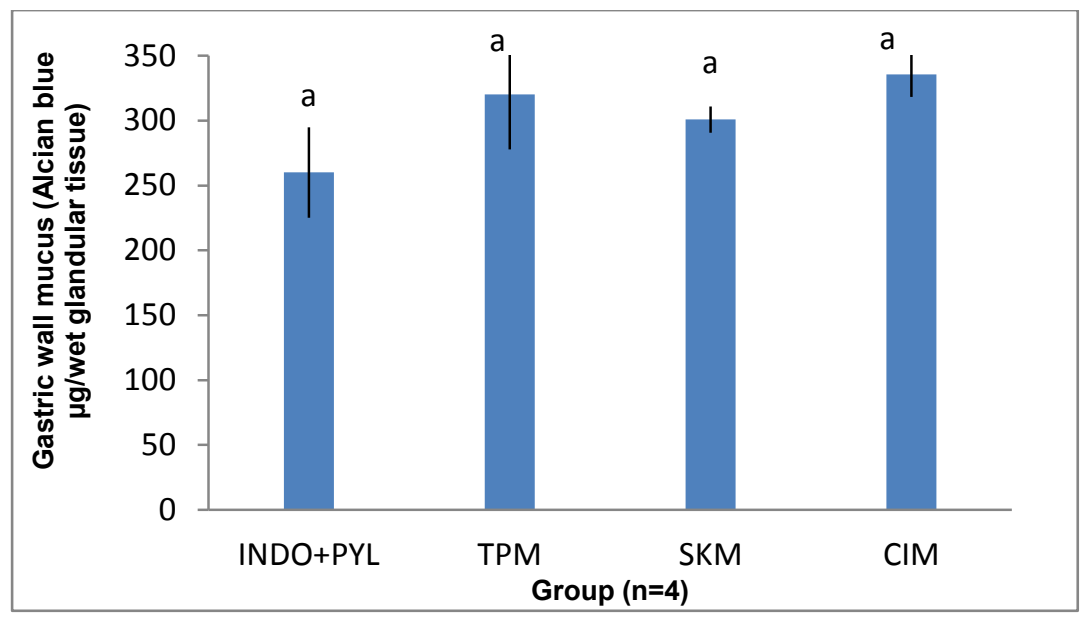

Figure 2. Increase in gastric wall mucus by the extracts.

The rise in the gastric wall mucus (GWM) by both the TPM and SKM is not statistically significant when compared to the induced group (INDO+PYL).

The volume of acid present in gastric secretion which comprises HCL, pepsinogen, mucus, bicarbonate, intrinsic factor and protein reflects acid volume. Exposure of the open lumen of the stomach to accumulating acid could facilitate ulceration [46]. Another aggressive factor responsible for ulcers is the amount of "acid present in the gastric juice. Over secretion of histamine contributes to increased secretion of gastric juice" [47]. When the concentration of hydrogen ions in gastric juice decreases, it indicates high $\mathrm{pH}$. The genesis of ulcer and gastric damage is made easy by hydrogen ions that serve as another aggressive factor [48].

Administration of tepal, skin and cimetidine at a dose of $100 \mathrm{mg} / \mathrm{kg}$ decreased gastric juice volume and increased gastric the juice $\mathrm{pH}$ when compared to the ulcer induced group. The increase in $\mathrm{pH}$ implies a decrease in gastric acidity which can occur through the decline in pepsin activity. Hence, the extracts prevent ulcer possibly by preventing overproduction of gastric acid. 
Mucus serves as the first line of defence against ulcerogenic agents. It is secreted by the mucous neck cells and shields the gastric mucosa. Mucus secretion is an essential factor in the protection of the gastric mucosa from the gastric erosions and has been regarded as a significant defensive entity in the gastric mucus barrier [49]. Increased mucus secretion by the gastric mucosal cells can protect gastric ulceration by several mechanisms, like decreasing of stomach wall friction during peristalsis and gastric contractions, increasing the buffering of acid in gastric juice and by acting as an effective barrier to back diffusion of $\mathrm{H}^{+}$ions [50]. Musa paradisiaca skin and tepal was found to augment the gastric mucus by decreasing the gastric juice acidity and lowering its volume, which are all evident in this work.

Topical and systemic effects of NSAIDs in the gastrointestinal mucosa are associated with mucosal damage in both the upper and lower GIT [51]. The systemic effects of NSAIDs involve the inhibition of prostaglandin production (by affecting COX-1 function), which defect bicarbonate and mucus secretion. Indomethacin induce a direct irritation effect by increasing free radical formation and $\mathrm{H}^{+}$ion transport [52]. Indomethacin causes ulcer mainly on the glandular (mucosal) part of the stomach [53]. The extracts $(100 \mathrm{mg} / \mathrm{kg})$ may also offer gastroprotection by enhancing the mucus wall thickness and antioxidant activity, since it was found to have an excellent DPPH radical scavenging activity [54] as well as the augmentation of the gastric wall mucus. It is possible that the cytoprotective action M. paradisiaca is mediated via the action of endogenous prostaglandin, which stimulate mucus secretion and plays an important role in ensuring mucosal integrity against the actions of various deleterious agents [55].

Several studies on the antiulcer efficacy of different parts of Musa paradisiaca var. sapientum were carried out, and it conforms to the current finding. A study conducted by Koffuor [56], showed that, the aqueous extract of Musa paradisiaca $(0.2-0.8 \mathrm{mg} / \mathrm{kg})$ treated mice gave a significant $(\mathrm{p}<0.001)$ reduction in the gastric ulceration, induced by acetic acid, similar to the esomeprazole treated group. The flower extract of Musa paradisiaca has been described to possess antioxidant as well as antiulcer activity [57,58]. Methanolic extract of M. sapientum var. paradisiaca showed antiulcer and mucosal defensive factors in normal and non-insulin dependent diabetes mellitus rats [59]. Studies with M. paradisiaca var. sapientum have shown its ulcer protective and healing activities through its predominant effect on various mucosal defensive factors and they resolved that its antioxidant activity may be implied in its ulcer protective activity [57]. A previous study reported that dried unripe banana powder contains flavonoid leucocyanidin and a significant protective role against aspirin-induced erosions was seen [55].

The significant increase in the antiulcer activity of Musa paradisiaca skin and tepal, could also be attributed to the presence of flavonoids and glycoside, which are shown to be present in the both tepal and skin extracts. In this study, the tepal extract showed better antiulcer activity as well as more abundant glycosides and phenols than the skin extract. The skin extract that showed antiulcer activity and also contains abundant flavonoids (Table 1). Among the phytochemicals present in the extracts, saponins and flavonoids are referred to as antiulcer compounds [60]. These phytochemical constituents of the extracts could explain its antiulcer activity. Furthermore, several plants containing high amounts of saponins have been shown to possess antiulcer activity in several experiments [61,62], probably acting as an activator of mucus membrane protective factors [63]. Moreso, the gastroprotective effect of flavonoids has been previously reported [64].

Phenolic compounds cause the augmentation of mucus production and anti-inflammatory action due to their free radical scavenging activity [65]. The tepal and the skin extracts of Musa paradisiaca were found to have a large amount of total phenolic content [54]. The presence of phenolic compounds in the extracts may be a contributing factor towards the significant reduction of ulcer index observed in the pre-treated groups. Musa paradisiaca contains a glycoside called "aucubin" which has antihistaminic activity [66]. Thus, the antihistaminic activity may be one of the mechanisms through which plant extracts prevent ulcer progression.

Mucosal defence and repair mechanisms are relevant in protecting the integrity of the mucosal layer, and resultant inhibition of these mechanisms could lead to necrosis. Examples of such defense mechanisms include preepithelial factors (mucus-bicarbonate-phospholipid barrier), surface epithelial cells connected by tight junctions, bicarbonate and mucus production, prostaglandins, heat shock proteins and blood flow through the mucosal vessels [67]. The extracts in effect, may directly protect the mucosal layer from harmful substances such as NSAIDs (indomethacin), acids and alcohol and stimulate mucosal regeneration. 


\section{Macroscopic observation}

Figure 3 showed the representative stomachs of mice after indomethacin plus pylorus ligation induced gastric ulcer. Oral administration of indomethacin $(48 \mathrm{mg} / \mathrm{kg})$ and ligation of pylorus produced superficial or deep erosions, bleeding, and antral ulcers. This is similar to the reports of Zhu and Kaunitz [3] and Lanza [68] in which prostaglandin and protective mucus function were inhibited by NSAIDs.

Nevertheless, pre-treatment with Musa paradisiaca skin and tepal significantly reduced the ulcer severity. Tepal and cimetidine were able to cause a significant reduction in ulcer indices compared to the ulcer induced group which caused a significant increase in the ulcer indices. Moreover, tepal and cimetidine have the same protective action against the induced ulceration. The decrease in ulcer indices is in line with those of Goel [69] who reported the reduction in ulcer indices on treatment with vegetable Musa paradisiaca in aspirin induced rats [69].

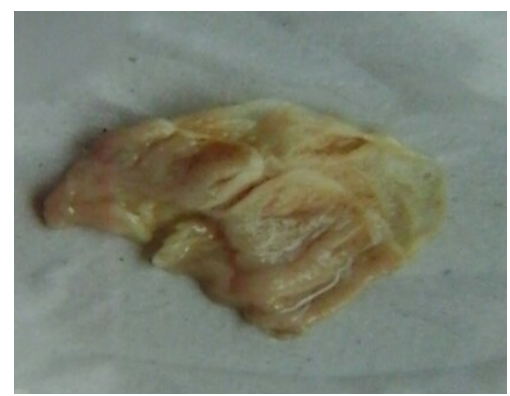

(A)

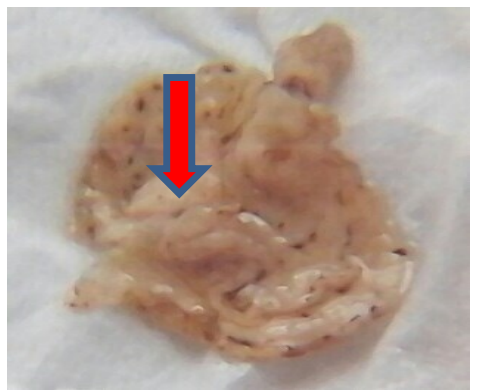

(B)

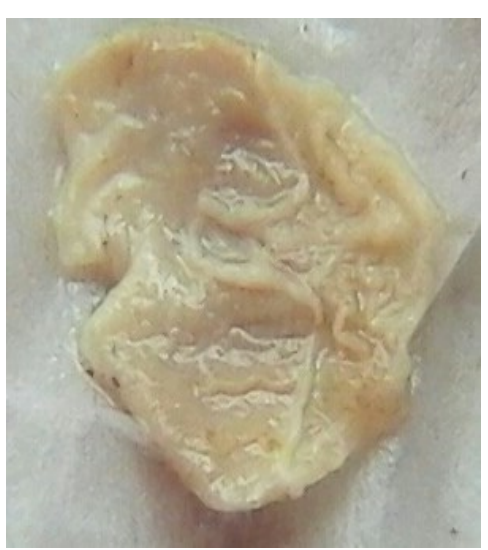

(C)

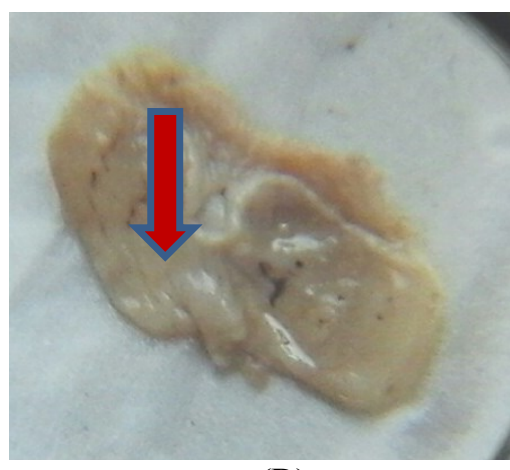

(D)

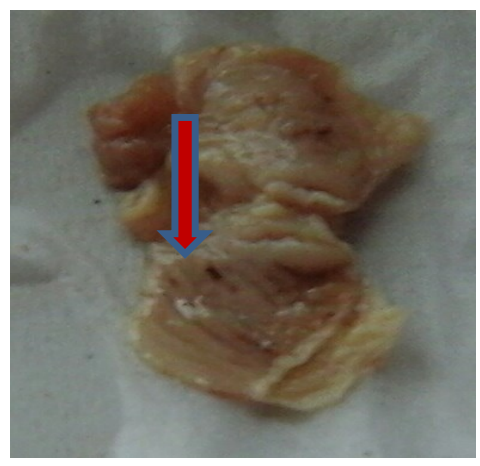

(E)

Figure 3. Gross view of mice stomachs after pre-treatment and ulcer induction. 
A: control stomach, showing normal gastric mucosa. B: ulcer induced stomach, showing various lesions and some inflammation. C: Tepal pre-treated stomach, showing a highly significant preventive effect against the IND+PYL induced ulceration. D: Skin pre-treated stomach, showing a mild preventive effect against IND+PYL induced ulceration. E: Cimetidine pre-treated stomach, showing prevention against the IND+PYL induced ulcer in the similar way as in $\mathrm{C}$.

\section{Histopathological studies}

This study also showed that, the administration of indomethacin at $48 \mathrm{mg} / \mathrm{kg}$ body wt. and the ligation of the pylorus, induced histological lesions in mucosal and submucosal regions as revealed by histological examinations compared to control group (Figure 4). This finding conforms to that of several studies in which ulcer was induced using indomethacin $[8,70,71]$ :

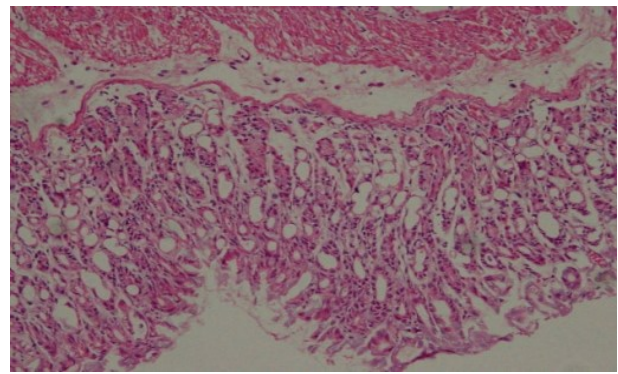

(A)

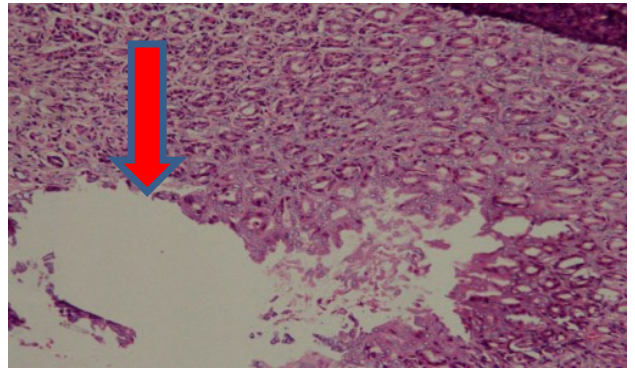

(B)

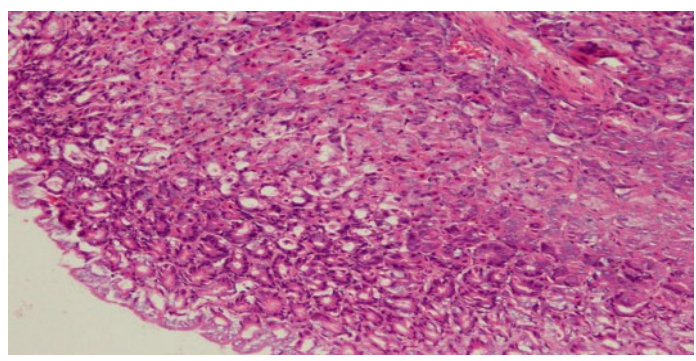

(C)

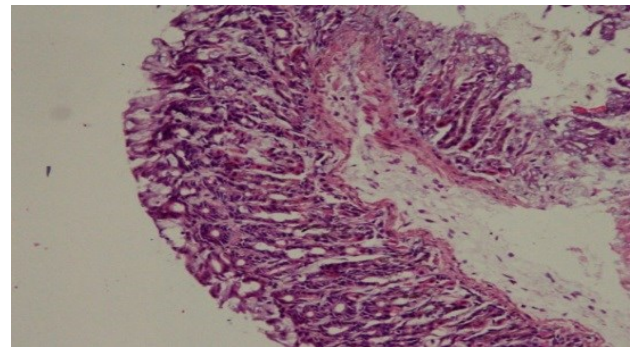

(D)

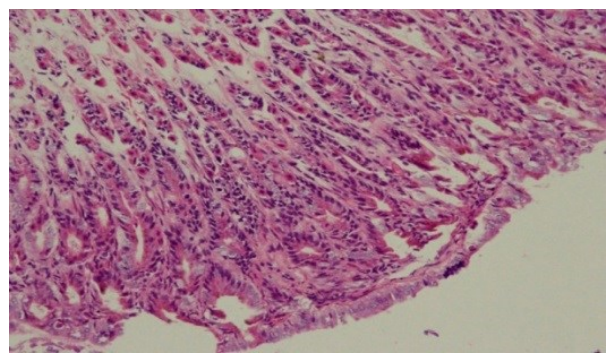

(E)

Figure 4. The histological view (x 100) of the stomach of mice

Control group showing intact mucosa (A). IND+PYL (B) induced highlighting the areas of congestion and erosions. Tepal pre-treated (C) showing intact mucosa. Skin pre-treated (D), with intact mucosa and decreased oxyntic cells in superficial half of mucosa and cimetidine (reference drug) pre-treated (E) also showing intact mucosa. 


\section{Conclusion}

In the present study, it was found that, the tepal extract has the highest preventive ulcer index that is statistically not significant when compared to standard drug (cimetidine), against the indomethacin plus pylorus ligation induced ulceration. Also the same tepal and the skin extract showed a promising reduction of gastric juice volume, increasing $\mathrm{pH}$ and strengthening of the gastric wall mucus. Phytochemical screening revealed the presence of flavonoids, saponins, glycosides and phenols in the extracts, which are especially higher in the tepal extract, which could be the reason for its higher antiulcerogenic action recorded in this work. Further investigations are needed to confirm the use of these parts of banana for ulcer treatment.

\section{Acknowledgement}

The researchers acknowledged the effort of Chemistry lab and animal house staff, in the Faculty of Medicine and Faculty of Bioresources and Food Industry, of Universiti Sultan Zainal Abidin (UniSZA) for their help in this research. The effort of Mrs. Ummi Akrimmah Binti Yim, a technician in Histopathology lab, Faculty of Medicine, UniSZA, is also appreciated. Regard to Eng. Dr. Rabiu Musa Kwankwaso (Kwankwasiyya) for sponsoring the study.

\section{References}

1. Amandeep, K., Robin, S. Ramica, S. and Sunil, K. (2012). Peptic ulcer. International Research of Journal of Pharmacy, 3 (6): 34 - 38.

2. Wallace, J L. (2001). Mechanisms of protection and healing: current knowledge and future research. American Journal of Medicine, 110: 19 - 23.

3. Zhu, A. and Kaunitz, J. (2008). Gastric mucosal defense. Current Gastroenterol Reports, 10: 548 - 554.

4. Robbin, S. L., Kumar, V. and Ramzi, C (2003). Acute and chronic inflammation In: Basic pathology. 7th Edition. Philadelphia. W.B. Company: pp. 333.

5. Suleyman, H., Demircan, B. and Karagoz, Y. (2007). Antiinflammatory and side effects of cyclooxygenase inhibitors. Pharmacology Reports, 59 (3): $247-258$.

6. Chattopadhyay, I., Bandyopadhyay, U., Biswas, K., Maity, P. And Banerjee, R. K. (2006). Indomethacin inactivates gastric peroxidase to induce reactive oxygen- mediated gastric mucosal injuty and curcumin protects it by preventing peroxidase inactivation and scavenging reactive oxygen. Free Radical Biology Medicine, 40(8):1397 - 1408.

7. Naito, Y. and Yoshikawa, $\mathrm{T}$ (2006). Oxidative stress involvement and gene expression in indomethacin induced gastropathy. Redox Reports, 11:243-253.

8. Motawi, T. K., Abd Elgawad, H. M. and Shahin, N. N. (2008). Gastroprotective effect of leptin in indomethacin-induced gastric injury. Journal of Biomedicine Science, 15: 405 - 412.

9. Abraham, C., Hart, J., Locke, S. M. and Baker, A. L. (2008). A case of indometacin-induced acute hepatitis developing into chronic autoimmune hepatitis. Nature clinical practice gastroenterol Hepatol, 5(3): 172 -176.

10. Kannappan, N., Jaikumar, S., Manavalam, R. and Kotti Muthu, A. (2008). Antiulcer activity of methanolic extract of Jatropa curcas (Linn.) on aspirin-induced gastric lesions in wistar rats. Pharmacology Online, 1: 279 $-293$.

11. Narayana, K. R., Reddy, M. S., Chaluvadi, M. R. and Krishna, D. R.(2001). Bioflavonoids classification pharmacology, biochemical effects and therapeutic potential. Indian Journal of Pharmacology, 33: 2-16.

12. Goel, R. K. and Sairam, K. (2002). Antiulcer drugs from indigenous sources with emphasis on Musa sapientum, Tamrabhasma, Asparagus racemosus and Zingiber officinale. Indian Journal of Pharmacology, 34: $100-110$.

13. Marie-Magdeleine, C., Udino, L., Philibert, L., Bocage, B. and Archimede, H. (2014). In vitro effects of Musa paradisiaca extracts on four developmental stages of Haemonchus contortus. Research in Veterinary Science, 96: $127-132$.

14. Sharma, P. C., Yelne, M. B., Dennis, J. J. Kadali. (2002) In: Data base on medical plants used in Ayurveda and Siddha. New Delhi: Public Printing, 5: 78 - 93.

15. Trease, G. E., Evans, W. C. (1989) Trease and Evan's Textbook of Pharmacognosy. 13th Edition London: Cambridge University Press: pp. 546. 
16. Mahmood, A., Mariod, A. A., Al-Bayaty, F. and Abdel-Wahab, SI. (2010). Antiulcerogenic activity of Gynura procumbens leaf extract against experimentally- induced gastric lesions in rats. Journal of Medical Plants Research ,4 (8): 685 - 691.

17. Morise, Z., Komatsu, S., Fuseler, J. W., Granger, D. N., Perry, M., Issekutz, A. C. and Grisham, M. B. (1998). ICAM-1 and P-selection expression in a model of NASID - induced gastropathy. American Journal of Physiology, 274: $246-252$.

18. Shay, M., Kamarov, S. A., Fels, D., Meranz, D., Gruenstein, H. and Siplet, H. (1945). A simple method for uniform production of gastric ulceration in the rat. Gastroenterology, 5: 43-61.

19. Kunchandy, J., Khanna, S. and Kulkarni, S. K. (1985). Effect of $\alpha 2$ - agonists clonidine, guanfacine and B-HT 920 on gastic acid secretion and ulcers in rats. Archives Internasional de pharmacodynamie et de therapie, 275: $123-138$.

20. Hano, J., Bugajski, J. and Danek, L.(1976). Effect of adrenergic blockade on gastric secretion altered by catecholamines in rats. Archivum immunologiae et therapiae experimentalis (Warsz), 24 (4): $507-524$.

21. Srivastava, V., Viswanathaswamy, A. H. and Mohan, G. (2010). Determination of the antiulcer properties of sodium cromoglycate in pylorus-ligated albino rats. Indian Journal of Pharmacology, 42 (3): 185 - 188.

22. Vinothapooshan, G. and Sundar, K. (2010). Anti-ulcer activity of Mimosa pudica leaves against gastric ulcer in rats. Research Journal of Pharmaceutical, Biological and Chemical Sciences, 1 (4): 606 - 614.

23. Corne, S. J., Morrisey, S. M. and Woods, K. J. (1974). A method for the quantitative estimation of gastric barrier mucus. Journal of Physiology, 2452: 116 - 117.

24. Bancroft, D., Stevens, A. and Turmer, R. (1996). Theory and practice of histological technique, 4th edition, Churchill Living Stone, Edinburgh, London, Melbourne: pp. 47 - 67.

25. Sheeba, M. S. and Asha V. V. (2006). Effect of Cardiospermum halicacabum on ethanol-induced gastric ulcers in rats. Journal of Ethnopharmacology, 106 (1): 105 - 110.

26. Bohlin, L., Goransson, U., Alsmark, C., Weden, C. and Backlund, A. (2010). Natural products in modern life science. Phytochemistry Reviews, 9 (2): $279-301$.

27. Doss, A. and Anand, SP. (2012). Preliminary Phytochemical Screening of Asteracanthalongifolia and Pergularia daemia. World Applied Science Journal, 18(2): 233 - 235.

28. Kubmarawa, D., Khan, M. E., Punah, A. M. and Hassan, M. (2008). Phytochemical screening and antibacterial activity of extracts from Parkia clappertoniana keay against human pathogenic bacteria. Journal of Medical Plants Research, 2 (12): 352 - 355.

29. Savithramma, N., Linga Rao, M. and Suhrulatha, D. (2011). Screening of medicinal plants for secondary metabolites. Middle-East Journal of Science Research, 8: 579 - 584.

30. Rupasinghe, H. P., Jackson, C. J., Poysa, V., Berado, C. D., Bewley, J. D. and Jenkinson, J. (2003). Soyasapogenol A and B distribution in Soybean (Glycine max (L.) Merr.) in relation to seedphysiology, genetic variability and growing location. Journal of Agricultural and Food Chemistry, 51: 5888 - 5894.

31. Anhwange, B. A. (2008). Chemical composition of Musa sapientum (Banana) peels. Journal of Food Technology, 6 (6): $263-268$.

32. Archibald, J. G. (1949). Nutrient composition of banana skins. Journal of Dairy Science, 32: 969 - 971.

33. Alisi, C S., Nwanyanwu, CE., Akujobi, C O. and Ibegbulem, C O. (2008). Inhibition of dehydrogenase activity in pathogenic bacteria isolates by aqueous extracts of Musa paradisiaca (var Sapientum). African Journal of Biotechnology, 7 (12): 1821 - 1825.

34. Middleton, E. J. and Kandaswanmi, C. (1992). Effects of flavonods on immune and inflammatory cell function. Biochemistry Pharmacology, 43 (6): 1167 - 1179.

35. Lewis D. A. and Shaw, G. P. (2001). A natural flavonoid and synthetic analogues protect the gastric mucosa from aspirin-induced erosions. Journal of Nutrition Biochemistry, 12 (2): 95 - 100.

36. Ragasa, C. Y., Martinez, A., Chua, J. E. Y. and Rideout, J. A. (2007). A triterpene from Musa errans. Philippine Journal of Science, 136 (2): 167 - 171.

37. Ghani, A. (2003). Medicinal plants of Bangladesh: Chemical constituents and uses. 2nd Ed. The Asiatic Society of Bangladesh, Dhaka, Bangladesh: pp. 315.

38. Ehiowemwenguan, G., Emoghene, A. O. and Inetianbor, J. E. (2014) Antibacterial and phytochemical analysis of banana fruit peel. IOSR Journal of Pharmacy, 4 (8): $18-25$. 
39. Mallikarjuna, R., Prasad, S. H. K. R. and Jyothirmayi, N. (2012). Efficacy of ripened and unripened fruit extracts of Musa X Paradisiaca L. (Bontha Cultivar) against human pathogens. International Journal of Pharmacy and Pharmaceutical Science, 4(1): 457 - 458.

40. Sairam, K., Rao, CV., Dorababu, M., Kumar, V., Agrawal, V. K. and Goel, R. K. (2002). Antiulcerogenic activity of methanolic extract of Emblica officinalis. Journal of Ethnopharmacology, 82: 1 - 9.

41. West, G. B. (1982).Testing for drugs inhibiting the formation of gastric ulcers. Journal of Pharmacology Methods, 8: 33 - 37.

42. Lam, E. K. Y., Tai, E. K. K., Koo, M. W. L., Wong, H. P. S., Wu, W. K. K., Yu, L., So, W. H. L. And Cho, W. C. H. (2007). Enhancement of gastric mucosal integrity by Lactobacillus rhamnosus GG. Life Science, 80: $2128-2136$.

43. Moraes, T. M., Kushima, H., Moleiro, F. C., Santos, R. C., Rocha, L. R. M., Marques, M. O., Vilegas, W. and Hiruma-Lima, C. A. (2009). Effects of limonene and essential oil from Citrus aurantium on gastric mucosa: role of prostaglandins and gastric mucus secretion. Chemico-Biology International, 180: 499 - 505.

44. Goel, R. K. and Bhattacharya, S. K. (1991). Gastroduodenal mucosal defense and mucosal protective agents. Indian Journal of Experimental Biology, 29: 701 - 714.

45. Mahmoud, M. K., Mohamed, Z. G. and Dalaal, A. (2001). Protective role of nitric oxide in indomethacin induced gastric ulceration by a mechanism independent of gastric acid secretion. Pharmacological Research, 43(5): $463-467$.

46. Olsen, C. E. (1988). Glutathione modulates toxic oxygen metabolite injury of canine chief cell monolayers in primary culture. Americal Journal of Physiology, 254: 49 - 56.

47. Grossman, M. I. (1978). Control of gastric secretion in gastrointestinal disease. Patho physiology-diagnosis and management. Sleisenzer, M.H, Fordtran, J.S., editors. 2nd ed. W B Saunders Co, Philadelphia: pp. 640 659.

48. Lullmann, H., Mohr, K., Ziegler, A. and Bieger, D. (2000). Color Atlas of Pharmacology. 2nd ed. Thieme Stuttgart, New York: pp. 166.

49. Goel, R. K., Maitri, R. N. and Mukobandhyay, K. (1994). Indian Journal of Experimental Biology, $32: 559$ 561.

50. Sanmugapriya, E. and Venkatraman, S. (2007). Antiulcerogenic potential of Strychnos potatorum Linn seeds on Aspirin plus pyloric ligation-induced ulcers in experimental rats. Phytomedicine, 14: 360 - 365.

51. Sostres C. and Lanas A. (2011). Gastrointestinal effects of aspirin. Nature Reviews Gastroenterology and Hepatology, 8 (7): 385 - 394.

52. Sharma, A., Chibber, S. S. and Chawala, H. M. (1980). Isocaviunin 7-gentiobioside, a new isoflavone glycoside from Dalbergia sissoo. Phytochemistry, 19 (4): 715.

53. Nwafor, P. A., Effraim, K. D. and Jacks, T. W. (1996). Gastroprotective effects of acqeous extracts of Khaya senegalensis bark on indomethacin-induced ulceration in rats. West African Journal Pharmacology and Drug Research: $46-50$.

54. Bashir, A. A., Khamsah, M. M., Abdurrazak, M., Mahadeva Rao, U. S. and Thant, Z. (2015). Phytochemical screening, antioxidant activity of pure syringing in comparison to various solvents extracts of Musa paradisiaca (banana) (fruit and flower) and total phenolic contents. International Journal of Pharmacy and Pharmaceutical Science, 7 (5): $242-246$.

55. Lewis, D. A., Fields, W. N. and Shaw, G. P. (1999) A natural flavonoid present in unripe plantain banana pulp (Musa sapientum L. var. paradisiaca L) protects the gastric mucosa from aspirin-induced erosion. Journal of Ethnopharmacology, 65 (3): 283 - 288.

56. Koffuor, G. A., Ainoonson, G. K., Amponsah, K. I., Addotey, J. N., Asiamah, E. A., Akuffo, S. K., Adutwum, K. and Bandoh, R. F. (2013). Anti-ulcerant activity of an aqueous fruit extract of Musa $x$ para-disiaca on acetic acid-induced gastric ulceration in ICR mice. Journal of Medical and Biomedical Science, 2 (2): 30 - 39.

57. Goel, R. K., Sairam, K. and Rao, C. V. (2001). Role of gastric antioxidant and anti-Helicobactor pylori activities in antiulcerogenic activity of plantain banana (Musa sapientum var. paradisiaca). Indian Journal of Experimental Biology, 39 (7): 719 - 722.

58. Vadivelan, R., Elango, K., Suresh, B. and Ramesh, B. R. (2006). Pharmacological validation of Musa paradisiaca bhasma for antiulcer activity in albino rats - a preliminary study. Ancient Science of Life, 25 (3-4): $67-70$. 
59. Mohan Kumar, M., Joshi, M. C., Prabha, T., Dorababu, M. and Goel R. K. (2006). Effect of plantain banana on gastric ulceration in NIDDM rats: Role of gastric mucosal glycoproteins, cell proliferation, antioxidants and free radicals. Indian Journal of Experimental Biology, 44: 292 - 299.

60. Lewis, D. A. and Hanson, P. J. (1991). Anti-ulcer drugs of plant origin. In: Ellis, G. P., West, G. B. (EDS.), Progress medicinal chemistry, Elsevier Science Publishers, London, 28: 2001 - 2031.

61. Yesilada, E. and Takaishi, Y. (1999). A saponin with anti-ulcerogenic effect from the flowers of Spartium junceum. Phytochemistry, 51 (7): $903-908$.

62. Morikawa, T., Li, N., Nagatomo, A., Matsuda, H., Li, X., Yoshikawa, M. (2006). Triterpene saponins with gastroprotective effects from tea seed (the seeds of Camellia sinensis). Journal of Natural Products, 69 (2): $185-190$.

63. Saito, H., Lee, Y. M., Takagi, K., Shoji, S. and Kondo, N. (1977). Pharmacological studies of Panacis Japonici Rhizoma. I. Chemical and Pharmaceutical Bulletin, 25 (5): 1017 - 1025.

64. Reyes, M., Martin, C., Alarcon de la Lastra, C., Trujillo, J., Toro, M. V. And Ayuso, M. J. (1996) Antiulcerogenicity of the flavonoid fraction from Erica andevalensis Cabezudo-Rivera. $Z$ Naturforsch C, 51 (78): $563-569$.

65. Di, C. G., Mascolo, N., Izzo, A. and Capasso, F. (1999): Old and new aspects of a class of natural therapeutic drugs. Life Science, 65: $337-353$.

66. Ahlborn M. L. (2013). Plantain: the benefits of the use of plantain in herbal preparations. [www.herballegacy.com] Availableat:http://www.herballegacy.com/Ahlborn_Medicinal.ht $m l$ [Date Access on: July 12 2015].

67. Laine, L., Takeuchi, K. and Tarnawski, A.(2008). Gastric mucosal defense and cytoprotection: Bench to Bedside. Gastroenterology, 135 (1): $41-60$.

68. Lanza, F. L. Chan, F. K. and Quigley, E. M. (2009). Guildelines for prevention of NSAID complicated ulcer. American Journal of Gastroenterology, 104(3): 728 - 738.

69. Goel, R. K., Chakrabarti, A. and Sanyal A. K. (1985). The effect of biological variables on the anti-ulcerogenic effect of vegetable plantain banana. Planta Medica, 51: $85-88$.

70. Ajeigbe, K., Oladejo, E., Emikpe, B., Asuk, A. and Olaleye, S. (2012). The dual modulatory effect of folic acid supplementation on indomethacin-induced gastropathy in the rat. Turkey Journal of Gastroenterology, 23(6): $639-645$.

71. Fleishman, M. Y., Zhivotova, E. Y., Lebedko, O. A. Deigin, V. I. and Timoshin, S. S. (2009). Protective effect of dermorphin analogue sedatin on indomethacininduced injury to the gastric mucosa. Bulletin Experimental Biology and Medicine, 148 (1): 60 - 63. 